\title{
Put SLACers to work for your library The Student Library Advisory Committee at Loyola University-New Orleans
}

$\mathbf{T}^{\mathrm{t}}$ he J. Edgar and Louise S. Monroe Library at Loyola University-New Orleans loves SLACers, Student Library Advisory Committee members that is. In 1994, the Monroe Library started SLAC in order to get more input from its primary users-students.

At the same time, plans were underway for a new library building, so SLAC served an important role in that process. Students were shown early architectural models, and since evolved into the library remaining open 24 hours during exams with student workers.

Almost 15 years later, SLAC continues to provide student feedback on library policies, services, and programs. In an average semester we have between 15 and 20 student members and 4 library staff, including the library dean, as permanent members. Students are eager to provide

\section{How to start an advisory committee}

- Seek nominations for members from campus organizations, such as Student Government and the Honors Program; ask faculty members to recommend active, engaged students; and consider asking members of your student staff to participate.

- Invite students to participate and explain the benefits of joining.

- When selecting library staff for membership on the committee, invite individuals who are student-centered, creative, open to suggestions and criticisms, and understand the library's strategic plans and vision.

- Select a meeting time that conflicts with the fewest number of classes; providing food boosts attendance!

- Plan to meet four-to-six times per academic year. Select agenda items for each meeting, and also include time for free discussion and open suggestions.

- Communicate with members between meetings. Keep students informed about actions taken in response to their suggestions. given the opportunity to ask questions and make suggestions. Feedback ranged from the food and drink policy to what equipment to supply in group study rooms.

SLAC at the Monroe Library provides more than just feedback to our questions; they also make suggestions and work with librarians to implement them. The earliest SLAC group worked with the Student Government Association to keep the library open for extended hours during the exam period using volunteers. This has opinions and suggestions, and a topic we introduce inevitably leads to discussion of several related points.

The students also initiate library improvements; these have included suggestions to make earplugs available for students who enjoy the active nature of the

Ashley Pillow is outreach coordinator at Monroe Library, Loyola University-New Orleans, e-mail: apillow@loyno. edu

๑) 2007 Ashley Pillow 
library's first floor but want to tune out the accompanying hum of activity, expanding the days during which the library is open for extended hours during final exams, and providing lockers for student use.

SLAC also serves as a focus group. When redesigning the library Web site a few years ago, SLAC members provided valuable feedback about how and why students use the Web site and what information they seek.

The students also provide insight into why online services are (or are not) used; feedback about language, location of links, and the types of media our students prefer is valuable for evaluating current services and planning for the future.

Some suggestions made by students are not feasible to implement, but we take every suggestion under consideration and keep careful documentation. It is critical to report back to students about actions taken on their concerns; this demonstration of our commitment to their concerns encourages future feedback.

("Student activism" cont. from page 638)

incredible new opportunities. Students stand to gain significantly from these changes. Many students are stepping forward to claim their rightful place, demanding a better future for scholarly communication. Librarians can encourage even more students to raise their voices and take action.

\section{Notes}

1. Søren Bertil Fabricius Dorch, "To students: Publish your essays and become world famous!" Copenhagen University Library (2007), www.kb.dk/en/kub/fag/nat/emner /oa_nyt.html.

2. Margaret Pickton and Cliff McKnight, "Research students and the Loughborough institutional repository," Journal of Librarianship and Information Science 38(4) (December 2006): 203-19.

3. Visit SPARC's site at www.arl.org/sparc/.

4. For more information about the Sparky Awards, visit www.sparkyawards.org/. z
The Monroe Library loves its SLACers, and the students enjoy the committee, as well. When asked what being part of SLAC meant, Gabriel Falcon ('07) responded:

Being a part of the Student Library Advisory Committee has been an amazing experience. It lets students know that the library is constantly trying to improve itself so that students can get the most out of such a valuable tool. Every suggestion made during meetings is taken in by the staff and they do their best to try and utilize these suggestions or find better ways of going about things in the library.

Loyola has an open period from 12:30 to 2:00 p.m. on Tuesdays and Thursdays known as the Window. No classes are scheduled during the Window, and so SLAC meetings are held at this time. The library provides lunch, and students provide thoughtful comments and suggestions for improving the library. $z$

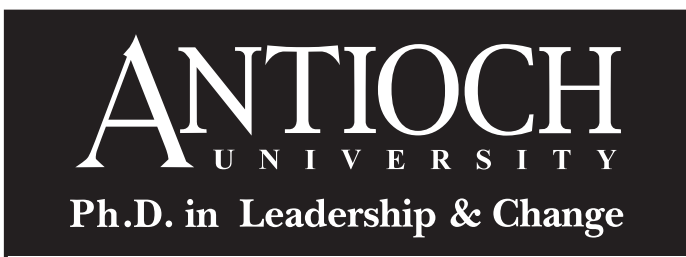

A low-residency program that combines faculty-mentored, individualized learning with a challenging interdisciplinary core curriculum

This distinctive program is for professionals seeking a degree that offers:

- Quarterly residencies

- Learner-centered focus

- Integration of theory and practice

- Flexibility of pace to completion

- Academic Mentoring

website: www.phd.antioch.edu 